\title{
Factors Limiting Nomination of Women Candidates for Elections in Nigeria
}

\author{
J. Tochukwu Omenma \\ Institute of African Studies, University of Nigeria, Nsukka \\ Email: tochukwu.omenma@unn.edu.ng
}

\section{J. Chisolum Onu}

School of General Studies, Social Science Unit, University of Nigeria

\section{Z. Onyinyechi Omenma}

Department of Social Science Education, University of Nigeria, Nsukka

Doi:10.5901/mjss.2016.v7n5p202

\section{Abstract}

\begin{abstract}
This paper interrogates constraints to women participation in elective politics from the point of party structure and organization mechanism. The paper is informed by the following statistic in Nigeria: in 2003 gubernatorial elections, 2 women candidates, (out of 72 Governors and Deputy Governors) were elected as deputy Governors. The results of 2011 elections show that only 7 women were elected as senators (out of 109) and 19 as members of the House of Representative (out of 360). This is a downward trend in comparison to 2007 elections when, 9 and 23 women were elected to the Senate and House of Representative, respectively. So far, not a single woman has been elected as Governor in Nigeria. Data sources consisted of governmental documents, party constitutions, oral interviews, data from non-governmental organizations such as European Election, Observation Mission (EU EOM), and observation of party meetings, conventions and congresses. Our findings show that lack of internal party democracy; which is as a result of private ownership of political party by godfathers (political notables); and weak executive committees are responsible for poor nomination of women candidates. Within this tight control of party organization by the godfathers, party members lost their democratic rights to participation in candidate nominations, and women group are the most disadvantaged. In as much as there are serious issues of lack of internal democracy, women condition will not likely improve in political participations.
\end{abstract}

Keywords: women nomination, godfatherism, stakeholders, internal democracy, party politics

\section{Introduction}

The literature on democracy is so vast and wide. The vastness of literature has resulted to narrowing down the concept to two distinctive categories - 'minimal' and 'maximal' (Munck 2011; O'Donnell 2010; Hobson and Kurki 2011; Kitschelt et al. 2010). The literature on minimalist democracy is on the quality of democracy which is concerned with empirical analyses, such as fair, competitive and recurring elections, popular participation, respect for human rights, and universal suffrage (Munck 2012; Levine and Molina 2011). On the other hand, the maximal scholars underscore the significance of end results or output of democracy, such as economic equality, social services/rights, responsiveness etc (Mazzuca 2010; Morlino 2004). Irrespective of the obvious distinction, the central elements of democracy are: existence of political parties, free competition, and the control of state power.

Literature on political parties have associated democracy with the existence and functionality of parties (Lipset and Rokkan, and Hoeane 2004; Matlosa and Karume (2004). Parties drive democracy and, democracy cannot be discoursed except in terms of how political parties function. It is not enough for parties to exist, such parties must accommodate various interest groups - minorities, women and physically challenged people within the polity.

Modern parties have been linked with several shortcomings among which are excessive factionalization, under representation of women and, problem of internal party democracy (Omenma et al 2014; International IDEA 2007, 2006). Added to this is the male-dominated party structure and in the decision-making process. In practice, not all political parties promote gender equality or uphold their manifesto as pledged. Data have shown few women holding top decisionmaking positions in their ranks (Omenma et al 2014). According to Mainwaring (1999), despite the shortcomings of political parties in many countries, parties continue to be the main agents of representation in democratic politics. 
Strategies to increase women inclusion into politics have taken different dimensions since third wave of democracy in Africa. In Nigeria, for instance, institutional and policy reforms have been initiated to accommodate minority interests, particularly women. In 2000, a National Policy on Women requested 30 per cent female representation in all levels of government. Also, the 2007 code of conduct for parties geared towards the promotion of active participation of women in electoral processes, and likewise, parties committed themselves against violence or intimidation of any kind (EU EOM, 2007). Particularly, the People Democratic Party (PDP) provides for affirmative action for women;

\begin{abstract}
A PDP led government will continue to pursue a policy of inclusiveness for women through programs that will address age long barriers imposed by cultural and economic factors ...Ensure equitable representation of women in all aspects of national life including party organs by using affirmative action to ensure that at least $35 \%$ of the workforce are women (PDP Manifesto, 2011-2015; p32).
\end{abstract}

On the government part, Independent National Electoral Commission (INEC) of Nigeria has been undertaking conscientious efforts at broadening voter education programme, targeting groups or citizens that might be least likely to participate, such as first time voters, minority groups and women.

Despite these inclusions of gender-friendly provisions, parties hardly respect their constitutional provisions. The optimism that the return of liberal democracy will likely lead to popular participation, particularly women participation and representation in politics are not matched with the realities on ground. This is article examines the internal party nomination process and constraints against the active participation of women in Nigerian politics. The paper draws attention to the fact that women participation in elections cannot be discussed in isolation of party nomination. In this paper, we examined internal party structure of PDP, the influence of godfather factor in the party's nomination of candidates and strategies of excluding women from party politics in Nigeria.

\title{
2. Research Methodology
}

The study adopted a survey design. Primary and secondary data were collected. Individual level opinions were sourced from politicians and party technocrats/officials, most importantly, from women party members and party executives. This was supplemented by observation of the compositions of party executive, party meetings and congress. Secondary evidence were obtained from party constitutions, Electoral Acts, International Institute for Democracy and Electoral Assistance (International IDEA), publications of the Independent National Election Commission (INEC) and Enugu State Independent Election Commission (ENSEC), etc. We reviewed related literature on women participation for clarification of concepts. Data were analyzed by logical inferences, content analyses and drawing conclusion from existing data.

\section{Conceptualizing Women's Political Participation}

Women participations in politics have attracted diverse attention from scholars and policy-makers. Phillips (1998); Bathla (1998); Rai (2000) among other scholars have contextualized women's political participation from the historical dominance of men in party politics and democracy. The authors argue that democracy had long ago served men better than women (Phillips 1998; Bathla 1998; Rai 2000). Women were relegated to the periphery of politics by early political philosophers such as Plato, Aristotle, Rousseau, John Lock, Thomas Hobbes and Hegel. These philosophers considered women fit only for domestic roles in the private sphere. From the classical era, women were not party of politics because of their suitability in caring roles as mothers and wives. The public-private divide remains as the foundation of the various forms of world democracies (Phillips, 1998, Rai, 2000). The ancient and modern democracies failed to recognize women as citizens, women were sidelined in both theory and practice (Bathla, 1998:39).

Relatedly, is the hierarchical and male-dominated party structures, which often provided unreceptive atmospheres for the pursuit of gender-sensitive policies and programmes. This underscores the ideological imagery of the masculinity and brutality of politics (Ibeanu 2009), which has been used to exclude women from politics. In many contexts, despite constitutional provisions toward decentralization in political structures, power structure is still concentrated in the hands of a small elite group (Big Man) at the top of party structures and key political decisions are being made behind closed doors without sufficient involvement of women (Pedwell 2008; Ibeanu 2009).

Another significant constrains to women's political participation is the lack of material resources available to women. In Nigeria, politics is about money, power and political networks (Adeyi 2008; Best 2008; Ayoade 2008). It is almost impossible to contest any election without adequate finance and access to political know-how and training. Because women are less integrated within powerful political and economic networks (Adeyi 2008), it is even more difficult 
for them to participate in large numbers or to play an important role in political decision-making. In Nigeria the situation is more obvious because of the poverty level that reduced politics to 'give-and-take affairs'. Adetula (2008:xxviii) argues that in Nigeria;

\begin{abstract}
Money politics is quickly shrinking the political space, becoming a key variable in determining who participates in electoral politics and how. For example, nomination fees for party members seeking elective positions have become so high that only the rich and daring "political entrepreneurs" can participate in party primaries. Women and youth are the most vulnerable in this situation because of their little or lack of access to wealth.
\end{abstract}

Today, money drowns votes and voices in Nigeria as 'godfathers' openly confess about shady deals, funding or sponsoring elections for 'godsons' and purchasing electoral victory.

Lack of democracy within political parties is the biggest impediment to women's political participation in Nigeria (International IDEA 2006). A party is seen as a cartel system and a conglomeration of economic investors that compete vigorously for access to state power. Agbaje and Adejumobi (2006:40) describe the powerful interest of this private power structure in charge of the political parties in Nigeria thus;

\begin{abstract}
They often constitute informal leaders, who are more powerful than the party chiefs and formal office holders. They sponsor candidates, control the internal party nomination process, finance electoral campaigns, rig elections on behalf of their candidates, corrupt election officials, and sometimes change the names of candidates after elections have been concluded. They are virtual kingmakers.
\end{abstract}

This phenomenon of private ownership of parties weakens internal party democracy while intra-party relationship is primarily a function of titanic struggles among these 'big men' or 'barons' within a political context of multi-religious divisions. Dahl (1971) argues that such extreme social polarization is detrimental to democratic consolidation, because group polarization turns easily into violent fights for the monopolization of the state. In sum, internal organizations of such parties are not rule-based and there is little democratic content in the process, while in election "people are voting without choosing" (Ake 1999:37). The failure to evolve internal democracy among political parties is a major challenge facing women participation in party politics in Nigeria.

\title{
4. Result Presentations
}

\subsection{Party Evolution in Nigeria}

Historical evolution of parties in Nigeria is categorized into four different phases. Each phase has important implications for internal party democracy. The phases are: (a) the pre-independence and immediate post-independence era-19231960; (b) the Second Republic political parties, 1979-1983; (c) parties for transitional democratic period 1990-1999; (d) and post-transitional democratic parties, 2003-2011. Each historical period has its peculiar characteristics and impact on democracy in Nigeria. There are general characteristics associated with political parties irrespective of period of its existence. These characteristics are:

- identity politics either in the form of ethnicity, religion, geo-political zone, or sub-group;

- party machineries revolving around powerful individuals or groups known as leader or godfather;

- the rank-and-file of political parties play marginal role in the decision-making process (nomination of candidates) of the party;

- party supremacy is replaced by the supremacy of the government over the party; and

- parties are property of rich individual driven by the desire to acquire state power by fair or foul means.

The character of political party from pre-independence to date shows a mosaic composition of factions and different forms of party membership. Parties are not formed on the basis of identifiable ideas or principles rather on primordial issues. The first generation of political parties (1923-1960s) were formed to actualize independence, the second generation was to displace the military from reign of power (1978-1982; 1998-2003) while the last generation of parties (2003-2011) were merely conglomeration of power-seekers.

There are five interfacing power blocs or social forces: ethnic forces, religion forces, military group, political godfather (barons/investors), and governors' forum. The first two groups were the dominant social forces during preindependence era, the first republic and second republic politics, while the last three groups are the new hegemonic power blocs. The emergency of the military group, political investors and governors' forum is due to the declining significance of religion and ethnicity in electoral politics in Nigeria. 


\subsection{Party Structures}

Party structure and organization is a top-bottom arrangement from the National level through the State, the Zones, the Local Government Areas and to the Ward levels. Based on article 10 of the Peoples Democratic Party's (PDP) constitution, the party's organs are constituted as follow (i) Ward Executive, (ii) Ward Congress (iii) Local government Executive Committee (iv) Local Government Area Congress (v) Senatorial District Working Committee (vi) State Caucus (vii) State Working Committee (viii) State Executive (ix) State Congress (x) Zonal Working Committee (xi) National Caucus (xii) National Working Committee (xiii) National Executive Committee (xiv) Board of Trustees (xv) National Convention. Party National Executive Committee (NEC) is the highest administrative organ of the party.

Diagram 1: Power structures and functioning of Party NECs

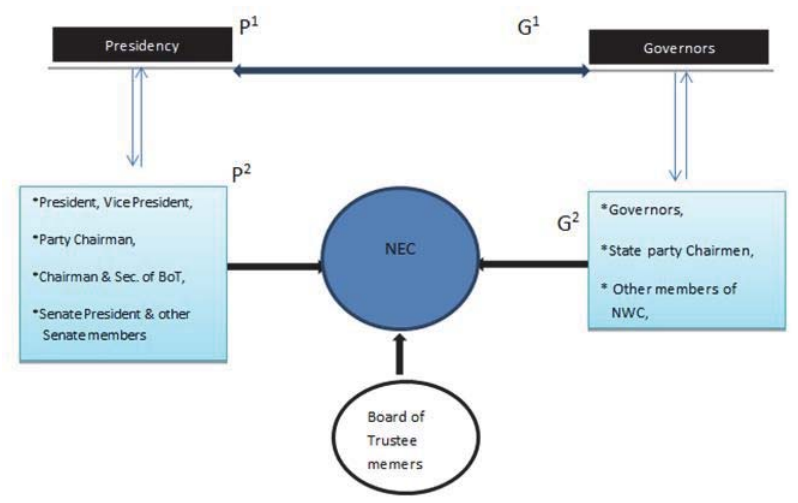

The public office-holders and non-public office-holders are categorized into three power blocs or cleavages (see diagram 1). The Presidency $\left(\mathrm{P}^{1}\right)$ is the leader of $\mathrm{P}^{2}$ power bloc, the Governors $\left(\mathrm{G}^{1}\right)$ are collectively and individually in charge of the political interest of the second power bloc $\mathrm{G}^{2}$, while the BoT is third power bloc. The capacity of $\mathrm{P}^{1}$ and $\mathrm{G}^{1}$ to control and direct NEC deliberations are dependent on their support base or grassroots strength as represented in $\mathrm{P}^{2}$ and $\mathrm{G}^{2}$. The influences of party godfathers filtered through the party structure. The structures and organs of political parties help them to effectively aggregate and process their parochial interests. Ibeanu (2009) points out that the process of party competition involves the existence of two parallel governments, Presidency $\mathrm{P}^{1}$ and Governors $\mathrm{G}^{1}$ on one hand, and party Executive on the other. One is the official, de jure party executive, while the other is the political machine, the de facto party executive (godfathers, represented in the diagram 1 as $\mathrm{P}^{1}$ and $\mathrm{G}^{1}$ ) who is really in control of party administration. De facto government, known as godfather, do not belief in mass political participation, because such is detrimental to his primitive accumulation of votes and capital. It is under this de facto governance that women participation in party politics is examined vis-à-vis the project of democratic consolidation.

Within the PDP structure, power does not lie with the party executives rather with the godfathers, represented in terms of governors, president or other influential public office holders. Party primaries, conventions and congresses are forums for nominating party candidates for elections and electing party officials. However, in practice, the organs make little or no reference to party constitution or other extant law regulating candidate nominations. The PDP is epic-centre of politics of godfatherism, barbarism, personality and military cult of the highest dimension. Horse-trading and culture imposition of preferred candidates have characterized the party primaries, congresses and conventions.

The organic interconnection between party godfathers and governors' forum is the character and context under which candidate nomination is undertaken. Party politics are characterized by: (a) the influence of money on competitive party and electoral politics; (b) the privatization of party politics; (c) disrespect for party regulations and programme; and (d) the escalation of election-related violence.

\section{Discussions}

Our analyses and discussions are based on the observations of party meetings and congress, and the informal power 
arrangement within party organization. The discussion pays particular attention to the unconstitutional but frequently used policy of nominations: anointed candidate; consensus candidates and automatic tickets (Omenma et al 2014:71). Given that, nomination is the most important predictive factor for women's representation, methods of party nominations becomes central to women participation. The centrality of parties to the participation in elective authorities in Africa is worsening because there is no constitutional provision for independent candidates. In Nigeria, Section 221 of the 1999 Constitution provides:

No association other than a political party shall canvass for votes for any candidate at any election or contribute to the funds of any party or to the election expenses of any candidate at an election.

The above provision effectually removes the possibility of independent candidacy in our elections and places emphasis and responsibility in elections on political parties. Without a political party a candidate cannot contest. Therefore, the ability of women to mobilize within parties and their willingness to challenge party hierarchies is crucial for women representation.

Following extant literature and data on party organizations, we identified and analyzed seven independent but interrelated factors whittling down women nomination opportunities in Africa. First explanation focuses on the godfather politics or what Sklar, Onwudiwe, \& Kew (2006) referred to as Big Man politics. The party structure is built around political merchants or barons, who consider politics as economic investment, rather than a process built on freedom, equality and fairness (Adejumobi, 2000; Agbaje and Adejumobi 2006; Fawole 2005; Barkan 1995, 2000). It is a process, referred to as machine politics or prebendal politics (Joseph 1988; Ibeanu 2009).

Money, influence and prebendal power structure are the hallmark of godfather politics. It is through these power factors that godfather or Big man controls party structures and regulate government institutions. Godfather politics is a condition whereby a wealthy individual or a coalition of rich individuals controls party structures and determine who gets 'what' 'how' and 'when'. Godfathers are both in literal and objective terms owners of political parties in Africa. Politics, for the godfathers, is a business investment driven by mercantilist ideology of surplus gain. Sklar et al (2006) describe their foundation on "...regular cash and carry kickback relationship". What differentiates godfather politics from political 'notables' in Europe and other older democracies is the godfather's penchant to operate outside party regulations and institutions of governance. Instead of the extant rules determining the relationship between godfather and his clients, it is the terms of illegal contract that determines the nature of public governance. This explains why the godfather subjects his client to illegal contractual arrangement before a shrine or multiple of shrines or oracles (Simbine 2004; Yahaya 2007; Ayodele 2008, Ibeanu 2009).

Godfatherism is characterized by "authoritarian political monopoly, defined as the absence of competition... and the elimination or subordination of rivals" (Jackson and Rosberg 1982:48). A godfather or a collation of godfathers determine members of nomination committee; pays the committee's hotel bills, feeding expenses, and daily allowances of members. Given this scenario, godfather controls all the relevant nomination materials, ranging from the membership lists, membership cards, ballot papers, nomination forms and official party seal. Under such tight control by the godfather, what plays out is the denial of nomination form to unwanted candidates, conducting of election in unauthorized/unknown venue, manifestation of irregularities in the names of delegates, hijacking of the accreditation tags and list and other fraudulent constrains (such as the use of personal trained 'army' or government security agents) to intimidate out opposition candidates. Members of party NECs are either a representative of godfathers or they themselves, in terms of some Governors, are godfathers and what manifest is the parcelling of party nomination slots to various godfathers.

The quest for women nomination under godfather controlled party organization has been successfully limited in numbers. It has been limited because: first, godfather-client relations are contractual and the contract is usually made binding through oath before a shrine, deity or oracle. This is unconventional and unconstitutional, and most women are unlikely to disparage themselves to oath taking before a shrine, deity or oracle without incurring the wrath of the family. Women are not attractive candidates for the godfather nomination system because of the unorthodox practice associated with godfatherism. For instance, evidence shows that out of four conservative election periods, Chairmanship position in seventeen (17) Local Council Areas in Enugu State, Nigeria, PDP had nominated once a woman candidate - Chief (Mrs) Oby Okafor - in 2004. It buttresses the fact that women are really unattractive candidates for the investment policy of the godfather. Second, a few women who may subject themselves to such nocturnal agreement are most likely to renege on the agreement. A woman politician, states that local women are agents of social and political change within local communities in Africa. Women have built age-long reputation of integrity, accountability and probity in terms of managing household fund. Therefore, most local women will not subscribe to a system of mortgaging public fund to an individual or groups of individual. Under this condition, women are unlikely candidates for the godfather politics. This agrees with Lindberg (2004) assertion that neo-patrimonialism is generally viewed as an important factor preventing women from participating in politics; while Tripp (2001) points that an increased political empowerment of women is antithetical to 
patrimonialism. Third, godfathers are merchants of fear, and they use violence freely to extract their path of agreement from their clients in the event of reneging. The fear of public outcry when maximum violence is used on women deters most godfathers from 'anointing' women as party candidates.

Second, is the stakeholder system which is a modification of godfatherism. Party stakeholders are individual party members loyal to the executive Governor or executive Local Government Chairman. Membership of the party stakeholders is at the discretion of the Governor, and they earn their remuneration from the benevolence of executive Governor or Council Chairman. Memberships of stakeholders are usually male-dominated. Stakeholder system is an informal arrangement operating outside party constitution. It exists in parallel with party executive at ward, local government or state levels; but wields more influence and power than the party executives. Members of party executive may or may not be members of the stakeholders, but some influential members of executive are co-opted. The membership of stakeholder is fluid as its function, but the primary function of stakeholder system is candidate recruitment and selection for the disguised godfather. Stakeholders act in tandem with the Governor to recruit candidate for nomination at party congresses. Stakeholder system operates under the most exclusive rules and important party decisions are taken by this group. In abstract term, party stakeholders are considered as the "owners of the party" but in objective condition parties are owned by state Governors. Stakeholders have a leader, who is the Governor that funds the party from government treasury, pays stipend to members of the stakeholder or award juicy contracts to them. Thus, stakeholder does the bidding of the Governor: adopt the Governor's choice of candidate for nomination, undertake written agreement or oath taking on behalf of the godfather-Governor, call the Governor's choice a "consensus" candidate, force the party executive to return the Governor's choice as being nominated by the party, and organize non-transparent and non-inclusive primary to endorse the Governor's choice.

The governors are 'leaders' or 'godfathers' of the party in their various States. At every national convention or state congresses, delegates queue behind their governors and that system ensure bloc vote, either by persuasion or through intimidation. That is how the governors streamlined the entire political contest and even the President or the national party chairman cannot disagree with the governor(s) and win the contest. They are collectively and individually political 'godfathers'. Collectively the Nigeria Governors' Forum (NGF) decides the next President, while at individual level Governors nominate who contest legislative positions at the National Assembly, state legislators, local government chairmen, senior officials of the party, federal ministers, and presidential aides. The Governors have been described as power terrorists by Prof. Aminu, a former Nigerian Senator. He states;

We are talking of terrorists in Nigeria; the main terrorists are members of the Governors' Forum. They are terrorizing ministers, senators and state assembly members. In fact, everybody in the country is under the threat of the Governors' Forum. It is not good for democracy and must be removed for the system to grow.

Following this procedure, women candidates suffer from several imputed prejudice from the party stakeholder. First, composition of stakeholder is male-dominated, just as party executive structures, therefore interest of women are poorly represented in the stakeholder system. Second, the likely marginalization of women by the stakeholder structure is based on erroneous argument that electorates are not ready to elect a woman (Ike Oloto, 2014: Interview). Therefore, it will be risky for the party to nominate women candidates based on the prejudice. Third, it boards on women consenting to stakeholders' terms of agreement, which Best (2008:61) points out that it "would impinge on the performance of the beneficiaries in public office, and this would more or less terminate the political careers of female politicians as such poor performance would likely be tied to their gender". Structurally, stakeholder system does not operate an open and transparent nomination process neither does their actions and inactions guided by party rules and constitution.

Third, is the nature of primitive accumulation of votes (PAV) at various party congresses and conventions. PAV is a worst outcome scenario adopted by party godfather or stakeholder to nominate the 'anointed' 'consensus' or 'automatic' candidates. Primitive Accumulation of Votes is a Nigerian version of crass manipulation of electoral process. Ibeanu (2009) notes that, PAV is an election characterized by extreme manipulations, open fraud and irregularities usually assisted by non-partisanship of the state institutions:- police, military, electoral management board (EMB) and state fund - are freely used for the purpose of achieving PAV. PAV is usually adopted when there are challenges to godfatherGovernor's candidates. Simpser described such manipulated election as having political benefits beyond victory itself. Simpser (2008:2) points out that;

Specifically, large-scale electoral manipulation may be harnessed to influence patterns of political participation. By leading to massive victory, for example, it can discourage opponents from joining or supporting rival parties, from voting, or from participating in other ways. 
Sweeping electoral fraud by the anointed or consensus candidate and his supporters (party executive) could reinforce perceptions that the godfathers/stakeholders are entrenched and likely to win always. In turn, such perceptions could deter would-be opponents from competing, joining other parties or separating from the incumbent's group and discourage other persons (godfathers) from funding opposition campaigns.

Primitive accumulation of votes significantly threatens women participants, even to the extent of pursuing alternative option outside the godfather/stakeholder structure. The frequent uses of PAV have overtime instilled fears in women and, subsequently resulted to their withdrawal from party politics. It has a gender implication also, because excessive election fraud is associated with violence and masculinity. Some of the women that sought to compete against "anointed" candidates by the godfather are normally eliminated, because they are seen as unviable "investment by godfathers" (Best 2008). Even though, all the parties have formal procedures for the nomination of candidates but such procedures are often unheeded; when they are adhered to, the godfathers have means of determining the outcomes which have not favoured women over the years, particularly at the grassroots.

Fourth, is the increasing use of violence at party primaries at all stages of party organizations. Currency of violence as a means of achieving political objective is a common trend in Africa. Since the return of democracy in Nigeria, in 1999, political conflicts have been on increase at every election periods (EU EOM, 2003, 2007 and 2011; ICG 2007). In addition to the threat of terrorism and militancy in the North West and Niger Delta respectively, there has been rise in kidnapping of political opponents, assassination of popular candidates, violent disruption of political meeting and campaign rallies and other untoward acts against life. These acts and threats of violence occur at intra-party and interparty levels, and it seems to be on increase as every election draws closer. Political sponsorship, recruitment and use of thugs, young unemployed, uneducated area boys sometimes addicted to drugs and often armed with traditional weapons or fire arms, are means of winning elections, both inter and intra election. Political godfathers and aspiring politicians have promoted and used the militia groups to exert power and influence, attain political office and provide an environment of conflict to screen other illegal activities (Omenma, 2011:7). To prosecute the policy of primitive accumulation of votes, godfathers uses armed youths and thugs in snatching of ballots boxes, thumb printing of ballots, vote buying, and writing fake results sheets. Party primaries have been veritable theatres of violence. In virtually all urban centres, large numbers of police, in some cases using armoured personnel carriers had to be deployed at the venues of the primaries to prevent fighting between thugs. In many cases, they had to use teargas to quell the fights. Political violence has been reported in most states of the federation during party nomination exercises.

Undoubtedly, violence had a negative impact on the electorate and deterred women from political participation. Intimidation, violence against voters, alleged threat to life and killings of party supporters are enough reasons for women to withdraw from party activities. Therefore, political violence has been associated as a strong factor disfranchising women to electoral process. Some of them were pressured to step down in favour of a male candidate and were victims of threats and physical violence.

Firth is the traditional age-long practice of women responsibilities which among other things excludes politics.

Since the universal masquerade was specifically made with the male image in mind, women face an enormous struggle when they also try to take part in it (Puwar, 2004: 94).

Quotation above epitomizes significance of traditional value and role of women in society. Women underrepresentation in politics is an age-long issue both in Africa and other continents, whether it is in emerging or old democracies. The problem in African is its persistence despite the subscription to liberal democracy by most countries. Traditionally, women's role is limited within domestic affairs - child-minders, tending to farm crops, cooking of food and attending to the needs of household members. There are two common assumptions about women with respect to governance. First, that women are "...too weak and emotional to exercise responsible leadership" (UNICEF, 2001: 256) and second, women possess "less personal autonomy" (OECD 2012) which make them to have limited influence over the decision-making processes that shape societies. This is particularly true in Africa, where customary, statutory, and religious laws continue to discriminate against women (House-Midamba 1996; Yoon 2001). This influences the consideration of women as perpetual "minors" or "second rate" citizen (Reid 1995:58; Furlong 2003; Taylor 2003:2) who are supposed not to do anything for themselves. The colonial and post-colonial structure reinforced the above assumptions in several ways. First, was the emergency of western education and training, which was provided for the men for colonial administrative convenience, while the women were not encouraged to acquire the western education, because of differences in roles. Therefore, men had the initial education edge, which offered foundation of the postindependence government. Women were equally disenfranchised at colonial periods in Nigeria, particularly Northern women who were granted right to vote in 1976. 
Sixth, is the infusion of foreign religion - Islamism and Christianity into the traditional African religion. On the part of Islam, women freedom are considerably reduced, their faces are not meant to be seen (Islamic dress and veiling - hijab), their voices were meant not to be heard neither does the religion permit political or any form of competition with men (Caldwell 1988; Mohanty 1991; Moghissi 1999; Shahidian 2003). Though, Islamism is dominant religion in northern Nigeria, with Muslim minorities in southern Nigeria. The women Muslim members are regulated by the Qur'an and other sacred writings of Islam. For the Christian women who venture into active politics, their moral conducts are questioned. Prince Ikechukwu Oloto, in an interview says that;

\begin{abstract}
...the churches are now encouraging women to participate, not in politics but in women social mobilization. What I found in churches or religion is that there is this feeling: it is a bad omen to be in politics.... It is this bad people, because elections are rigged, there are violence and so, these occurrences are attached to personalities or the participants, so when they (church) weigh the positive and negative part of the entire system, because these people are corrupt, then the church prefers women to participate in social mobilization, in terms of religious preaching, good habits, good behaviour and good governance. But then, when it comes to elective position, if a woman is totally involved in politics, there is even the way the church looks at the person. There are certain things that are not even said in public. So they look at even women who have gone beyond social mobilization as being "one among them" not "one among us" (Prince Oloto, 2014 interview).
\end{abstract}

And because, religion and politics are interwoven in the traditional African setting, political parties covertly label women who dare into participatory politics as being morally bankrupt and not worthy to lead. Osedeme (2003:7) reported of an allegation where the National Vice Chairman East of one of Nigeria's leading political parties called the National Women's Leader a 'street woman' for holding and expressing a contrary opinion on some controversies in his region. Such statements are not only used by men to discredit women eligibility but they have damaging effects on women marital union and matrimonial home.

Finally, in addition to religion, local societies are organized along pre-capitalist forms of social organization, which are characterized by kin-based patrilineal extended families, male domination, early marriage (and consequent high fertility), son preference, restrictive codes of behaviour for women, and the association of family honour with female virtue. Beall, (2005) is of the opinion that when social institutions are deeply patriarchal and resistant to progressive social change, they can act as a real brake on the agenda for gender equality. These are social conditions which are prevalent in African culture that are linked to the limitation of women participation in politics.

\title{
6. Conclusion
}

Logically, it will be incorrect to continue to insist on socio-cultural and religious issues as major constraints to women representation politics in $21^{\text {st }}$ century. Insistence on such traditional factors will be a disservice to the huge enlightenment campaigns and contributions of feminist activists, Beijing conference on women, United Nation Resolution 1325, NEPAD and the AU and the African Protocol on the Rights of Women and host of other resolutions. To use traditional factor as a reason for women underrepresentation will amount to not recognizing the increasing number of female parliamentarians at national politics. INEC Report on the 2011 general elections shows that eight (8) women were elected as Senators, twenty two (22) females elected as members of Federal House of Assembly, while fifty four (54) women were elected into State Houses of Assembly. Their numbers have increased compared to other past election periods. The international efforts have impacted positively on the women in politics in Nigeria. But the nature of godfather politics which subjects party organization to the godfather's whim and caprices is a contemporary threat to women representation at executive positions - Governor, Chairman of Local Government or Party Chairman - or might have rolled back gains made by feminist activists.

\section{References}

Adam Przeworski, Michael Alvares, Jose Antonio Cheibub, and Fernando Limongi, "What Makes Democracies Endure?" Journal of Democracy 1 (January 1996): 50-51.

Adejumobi, S., (2000) "Elections in Africa: A Fading Shadow of Democracy?". In International Political Science Review, vol. 21, no. 1, 2000.

Adetula, V. A. O. (2008). Money and Politics in Nigeria: an Overview. In V. A. O. Adetula (ed): Money and Politics in Nigeria, Nigeria: International Foundation for Electoral System (IFES-Nigeria).

Adeyi, E. M. (2008). Funding of Political Parties and Candidates in Nigeria: Analysis of the Past and Present. In V. A. O. Adetula (ed): Money and Politics in Nigeria, Nigeria: International Foundation for Electoral System (IFES-Nigeria). 
Agbaje A. and S. Adejumobi, (2006). "Do Votes Count? The Travails of Electoral Politics in Nigeria". In Africa Development, Vol. XXXI, no. 3.

Ake, C. (1985). The Future of African States in Africa. International Political Science Review.

Allah-Mensah, B. (2001). "Political Parties, Gender and Representation: The Case of Ghana's Election 2000". In J.R.A Ayee (ed) Deepening Democracy in Ghana: Politics of the 2000 Elections, Vol.One Freedom Publications: Accra.

Allah-Mensah, B. (2005). Women in Politics and Public Life in Ghana. Friedrich-Ebert-Foundation: Accra.

Ayoade, A. A. (2008). Godfather Politics in Nigeria. In V. A. O. Adetula (ed): Money and Politics in Nigeria, Nigeria: International Foundation for Electoral System (IFES-Nigeria).

Best, K. C. (2008). Gender, Money and Politics in Nigeria. In V. A. O. Adetula (ed): Money and Politics in Nigeria, Nigeria: International Foundation for Electoral System (IFES-Nigeria).

Collier, D., and S. Levitsky (1997). 'Research Note: Democracy with Adjectives: Conceptual Innovation in Comparative Research', World Politics 49 (3): 430-451.

David B.(1993). "Liberal Democracy and the Limits of Democratization". In David Held (ed), Prospects for Democracy: North, South, East, West, Polity Press: Cambridge.

Farzana B. (2005). Women's Political Participation: Issues and Challenges Division for the Advancement of Women (DAW) Expert Group Meeting Enhancing Participation of Women in Development through an Enabling Environment for Achieving Gender Equality and the Advancement of Women Bangkok, Thailand, 8-11 November 2005-10-29

Held, D. (1987) Models of Democracy. Cambridge: Polity Press.

Hobson, Christopher and Milja Kurki (eds). 2011. The Conceptual Politics of Democracy Promotion. New York: Routledge.

Hoeane T, "Under Strain: The Racial/Ethnic Interpretation of South Africa's 2004 Election" (2004) 3 (2) Journal of African Elections 3.

Ibeanu, O. O. (2009). "Conceptualizing the Specificities of Direct Capture in the 2007 Elections". In Ibrahim, J and O. Ibeanu (ed), Direct Capture: The 2007 Nigerian Elections and Subversion of Popular Sovereignty. Abuja: Centre for Democracy and Development.

International IDEA (2006). Nigeria: Country Report based on Research and Dialogue with Political Parties. Sweden: International Institute for Democracy and Electoral Assistance.

International IDEA (2007). "Political Parties in Southern Africa: The State of Parties and their Role in Democratization". Report prepared for the International Institute for Democracy and Electoral Assistance (International IDEA) as part of its global Programme on Research and Dialogue with Political Parties. Sweden: International IDEA.

Kitschelt, H., Kirk H., Juan P. L., Guillermo R. and E. Zechmeister. (2010). Latin American Party Systems. New York: Cambridge University Press.

Krook, M. L. (2010) Quotas for Women in Politics: Gender and Candidate Selection Reform Worldwide. New York: Oxford University Press.

Levine, D. H. and J. E. Molina (2011). "Evaluating the Quality of Democracy in Latin America," pp. 1-19, in Daniel Levine and José Enrique Molina (eds.), The Quality of Democracy in Latin America. Boulder, Col. Lynne Rienner Publishers.

Lijphart, Arend (1999) Patterns of Democracy: Government Forms and Performance in Thirty-Six Countries. New Haven: Yale University Press.

Lindberg, S.I (2004). "Women's Empowerment and Democratization: The Effects of Electoral Systems, Participation, and Experience in Africa". Studies in Comparative International Development, Spring 2004, Vol. 39, No. 1, pp. 28-53.

Matlosa, K and Karume, S (2004) "Ten years of democracy and the Dominant Part System in South Africa", Election Update 2004: South Africa, no. 5, 30 March, EISA

Mazzuca, S. (2010). "Access to Power Versus Exercise of Power: Reconceptualizing the Quality of Democracy in Latin America." Studies in Comparative Development Vol. 45, № 3: 334-57.

Morlino, L. (2004). "'Good' and 'Bad' Democracies: How to Conduct Research into the Quality of Democracy." Journal of Communist Studies and Transition Politics Vol. 20, № 1: 5-27.

Munck, G. (2011). "Democratic Theory After Transitions From Authoritarian Rule." Perspectives on Politics Vol. 9, № 2: 333-43.

Munck, G. (2012). "The Origins and Durability of Democracy," pp. 3-20, in Peter Kingstone and Deborah J. Yashar (eds.), Routledge Handbook of Latin American Politics. New York: Routledge Press.

O'Donnell, G. (2010). Democracy, Agency, and the State: Theory with Comparative Intent. Oxford: Oxford University Press.

Omenma, J. T, Ibeanu, O. O. \& Onyishi, I. E (2014). Party Nomination Techniques in Nigeria: Their Impact on Women Representation in Local Politics in Enugu State, 199-2013. Journal of Gender, Information and Development in Africa (JGIDA) Volume 3, Numbers $1 \& 2$, Pp 57-88.

Omenma, J. T. (2011). "Oil Resources, Militancy, and the Post-Amnesty Challenges in the Niger Delta, Nigeria". Cranfield University Journal of Security Sector Management (JofSSM), Volume 8, Issue 3, September, 1-32. http://www.ssronline.org/jofssm/ issues/2011_8_3_02_amnesty_article.pdf?CFID=3557694\&CFTOKEN=10229569

Osedeme, D. (2003) "Fundamental Rights, women and the Constitution" in Women in Public Life. July-September, Gender and Development Action (GADA) p. 7

Pedwell, C. (2008). "Just Politics Women transforming political spaces" OneWorld Action: Gender Institute London School of Economics.

Peoples Democratic Party (PDP), Constitution of PDP 2009 (as amended).

Rai M. S. (2000). International Perspective on Gender and Governance. Macmillan Press, Great Britain.

Reilly, B. (2012) Electoral system options for Mongolia, UNDP Consultancy Report

Schumpeter, J. A. (1942). Capitalism, Socialism, and Democracy. New York: Harper. 
Sklar, R., Onwudiwe, E. \& Kew, D (2006). Democracy in Nigeria: Completing Obasanjo's Legacy. The Guardian. Sunday, October 1,pp $76-77$

Tripp, A. M. (2000). Women and Politics in Uganda. Kampala: Fountain Publishers.

Tripp, A. M. (2001). "Women's Movements and Challenges to Neo-patrimonial Rule: Preliminary Observations from Africa." Development and Change 32: 33-54. 